УAK 347.157

DOI https://doi.org/10.32837/chc.v0i37.357

Тищук Наталія Олексіївна,

аспірант кафедри цивільного права

Національного університету "ОАеська юридична академія"

ORCID https://orcid.org/0000-0002-6068-9263

\title{
ВЧИНЕННЯ ПРАВОЧИНІВ НЕПОВНОЛІТНІМИ ОСОБАМИ В УМОВАХ РОЗВИТКУ ІНФОРМАЦІЙНИХ ТЕХНОЛОГІЙ
}

Постановка проблеми. ОАнією з умови Аійсності будь-якого правочину $є$ віАповіАність особи, яка його вчиняє, необхіАного обсягу цивільної Аієздатності. Неповнолітні особи мають можливість вчиняти набагато ширше коло правочинів порівняно з малолітніми особами, разом із тим $€$ обмежено АієзАатними порівняно з особами, які досягли повноліття та набули повного обсягу аієзаатності.

В результаті стрімкого розвитку інформаційних технологій, які застосовуються Аля вчинення правочинів, обізнаності піАлітків у використанні таких технологій і масового переходу на покупки в режимі онлайн, безготівкові форми розрахунків, впровадження різного роду сервісів, які обслуговують цю сферу, виникає питання про розширення фактичних можливостей неповномітніх вчиняти правочини та вчинення їх в межах правових норм.

Аналіз останніх АосліАжень і публікацій. АосліАженню питань правосуб'єктності фізичних осіб, в тому числі неповнолітніх, приділяли увагу вчені Н.В. Волкова, А.В. Горбась, Ю.А. Аербакова, О.І. Карпенко, М.В. Аогвінова, С.Я. Ременяк, Ж.^. Чорна, Р.В. Чорнолуцький та інші. Вчиненню правочинів фізичними особами залежно віА обсягу Аієздатності приАіляли увагу вчені Т.В. Водоп'ян, І.В. Аавидова, О.С. Іоффе, Н.С. Кузнецова, В.В. Ауць, Р.А. МайАаник, М.В. Міщенко, Є.О. Харитонов, В.П. Шахматов та інші. Разом із тим особливостям вчинення правочинів неповнолітніми особами віАповіАно Ао їх віку в умовах інформатизації суспільства окрема увага не приАілялася.

Метою статті $€$ аналіз законодавчо схвалених видів правочинів, які можуть вчиняти неповно- мітні особи в межах обсягу своєї Аієздатності; визначення особливостей вчинення правочинів неповнолітніми особами в умовах інформатизації суспільства та розвитку інформаційних технологій.

ВикиаА основного матеріалу АосліАження 3 повним обґрунтуванням отриманих наукових результатів. На відміну віА кола правочинів, які можуть вчиняти малолітні особи, неповнолітні особи (Аіти у віці віА 14 до 18 років) мають значно більші межі правочиноздатності. Можна виАілити такі групи правочинів, які неповнолітня особа може вчиняти самостійно:

1) правочини, які знаходяться в межах ії цивільної АієзАатності та віАповіАно Ао законодавства можуть вчинятися самостійно (віАповіАно АО ч. 1 ст. 31 цК України це Арібні побутові правочини);

2) самостійно укладати договір банківського вкладу (рахунку) та розпоряАжатися вклаАом, внесеним нею на своє ім'я (грошовими коштами на рахунку);

3) правочини, які знаходяться поза межами її цивільної Аієздатності і які згодом були схвалений ї̈ батьками (усиновлювачами) або одним із тих, з ким вона проживає, або піклувальниками (ч. 1 ст. 222 ЦК України).

Також зазначені особи можуть самостійно:

1) розпоряджатися своїм заробітком, стипенАією або іншими Аоходами;

2) заійснювати особисті немайнові права на результати інтелектуальної, творчої Аіяльності, яка охороняються законом;

3) бути учасником (засновником) юридичних осіб, якщо це не заборонено законом або установчими Аокументами юридичної особи. 
За згодою батьків (усиновлювачів) або піклувальників неповнолітні особи можуть вчиняти такі правочини:

1) розпоряАжатися грошовими коштами, внесеними повністю або частково іншими особами у фінансову установу на їі ім'я;

2) щодо транспортних засобів або нерухомого майна - згода батьків (усиновлювачів) або піклувальника повинна бути оформлена у письмовій формі та посвідчена нотаріально, а також необхідним $€$ отримання Аозволу органу опіки та піклування.

Аалі охарактеризую зазначені види правочинів більш детально за зверну увагу на Аеякі їх особливості. Зокрема, коли йдеться про укладення "Арібного побутового правочину" неповнолітньою особою, то він буде віАрізнятися віА правочину 3 аналогічною назвою, укладеного малолітньою особою. Це пояснюється тим, що вік неповнолітньої особи тягне якісну зміну трактування поняття "Арібного побутового правочину", аАже такі особи порівняно $з$ малолітніми мають інший рівень фізичного, Ауховного та соціального розвитку, інші «побутові» потреби тощо.

Важливим є право неповнолітньої особи самостійно розпоряАжатися своїм заробітком та іншим Аоходом, Ае піА іншими Аоходами може розумітися винагорода за виконання цивільно-правових Аоговорів, АохоАи віА піАприємницької Аіяльності, АОхоАи ВіА Участі В Аіяльності юриАичних осіб, Аоходи віА реалізації майна чи віА його використання, а також всі інші доходи, які не є заробітною платою чи стипенАію, $є$ особистим АОходом неповнолітнього у грошовій формі [1, с. 445].

Самостійно розпоряАжатися такими АохоАами неповнолітній має право не в будь-який спосіб, а лише в межах Аій, передбачених ст. 31, п.п. 2-4 ч. 1 ст. 32 цК України, тобто неповнолітній має право використати зароблені кошти на укладення Арібних побутових правочинів, Аоговору банківського рахунку (вкладу), однак не має права на укладення інших Аоговорів (зокрема, укладення договору на навчання, приАбання комп'ютеру). Також законодавством дозволено неповнолітнім особам віАкривати поточні і вкладні (Аепозитні) рахунки, зокрема Аля зАійснення піАприємницької, незалежної професійної Аіяльності та Аля власних потреб.

Відповіано Ао пункту 7.4. Інструкції [2] неповнолітня особа має право самостійно розпоряАжатися внесеними нею коштами на рахунок, віАкритий нею на своє ім'я, а також заробітною платою (заробітком), стипендією або іншими
Аоходами, які надходять на її рахунок. Неповнолітня особа розпоряджається коштами, внесеними на поточний рахунок неповнолітньої особи будь-якою іншою особою, за згодою органу опіки та піклування та батьків (усиновителів) або піклувальників. Отже, якщо неповнолітня особа уклала Аоговір про розпоряАження своїми майновими правами інтелектуальної власності, вона має право відкрити рахунок Аля зарахування оплати за цим Аоговором і самостійно розпоряАжатися такими коштами [3, с. 72].

Важливою правомочністю Аля неповнолітньої особи є можливість самостійно заійснювати права на результати інтелектуальної, творчої діяльності, що охороняється законом, піА чим мається на увазі самостійне використання особою як особистих немайнових прав інтелектуальної власності, закріплених у ст. 423 цК України, так і майнових прав інтелектуальної власності, закріплених у ст. 424 ЦК України. Причому заійснення неповнолітнім цих прав не може бути обмежене чи скасоване, хоча право розпорядження Аоходом, одержаним віА їх використання, може бути обмежене або скасоване.

Крім правочинів, які неповнолітні особи можуть вчиняти самостійно, Аосить велику групу складають правочини, які вони можуть вчиняти лише за згодою батьків (усиновлювачів) або піклувальників. ВіАповіАні правочини вчиняють самі неповнолітні, а батьки (усиновлювачі) або піклувальники лише Аають згоду на його вчинення. Ао таких належать правочини щоАо розпоряАження грошовими коштами, внесеними повністю або частково іншими особами у фінансову установу на її ім'я; транспортних засобів або нерухомого майна - згода батьків (усиновлювачів) або піклувальника повинна бути оформлена у письмовій формі та посвідчена нотаріально, а також необхіАним є отримання Аозволу органу опіки та піклування тощо. Оскільки згода на правочин батьків (усиновлювачів) або піклувальників $€$ елементом правочину, то вона має бути надана в тій формі, в якій вчиняється правочин (окрема вимога щодо правочинів із нерухомістю та вимоги ст. 71 ЦК Україна та ст. 177 СК України Аля правочинів, які вчиняються з Аозволу органів опіки та піклування, який надається опікуну або піклувальнику).

В Аеяких випадках вчинення правочину неповнолітньою особою передбачає наявність згоди обох батьків, навіть якщо вони спільно не проживають. Частиною 5 ст. 177 СК України переАбачено, що за певних умов Аосить буде згоди й одного з батьків. На Аумку 3.В. Ромовської, це 
означає поступовий перехіА Ао встановлення виключної опіки (піклування) наА Аитиною того з батьків, хто проживає з нею [4, с. 248].

Якщо ж правочин зАійснено неповнолітньою особою без згоди батьків (усиновлювачів) або піклувальника і згодом він не був схвалений, то насліАки такого правочину визначаються віАповіАно до ст. 222 ЦК України.

Ю.І. Чалий вказує на необхінність розширення обсягу Аієздатності неповнолітніх фізичних осіб стосовно їх участі в особистих немайнових правовідносинах, які забезпечують природне існування та соціальне буття, та в майнових правовідносинах, пов'язаних із наданням освітніх послуг [5, с. 413]. Автор слушно аналізує такий елемент правосуб'єктності неповнолітніх (у широкому значенні) як можливість їх активної участі, тобто самостійно (не через дії представників) у майнових правовіАносинах. Обсяг майнової АієзАатності неповнолітніх визначається нормами ст. 32 ЦК України, однак аналіз практики свідчить на користь того, що неповнолітні є безпосередніми активними учасниками більш ширшого кола майнових віАносин, ніж передбачених цими нормами (зокрема, це відносини з надання освітніх послуг) [5, с. 414].

Повертаючись Ао питання про вчинення правочинів неповнолітніми, необхідно мати на увазі, що правочини з розпоряАженням коштами, цільовим або вільним, законного представника або третьої особи можуть виходити за межі обсягу їх цивільної дієздатності. Саме ці правочини характеризують стан Аієздатності неповнолітнього, якому батьками надана велика свобода дій. Контроль за зАійсненням подібних правочинів з боку законних представників неповнолітньої особи полягає в тому, чи налає батько у розпорядження неповнолітньому певну грошову суму чи ні, встанов^юється чи ні мета її використання. Тому й весь ризик нецільового використання коштів, наданих у розпоряАження неповнолітньої особи, покладається на ії законних представників.

Цікавою є й ситуація з вчиненням правочинів щодо Аарування (коли Аарувальником $€$ неповнолітня особа). Такі правочини неповнолітніх за розпорядженням коштами, наАаними законними представниками або третіми особами, обмежуються мише розпорядженням саме цими засобами, але не майном, придбаним на них. Тому практично всі правочини неповнолітнього по Ааруванню, в яких неповнолітній виступає дарувальником, за деякими винятками є формально нікчемними. ОАнак на практиці ніхто ніколи їх не реанімує [6, с. 110].
Погоджуюся 3 Ю.І. Чалим, який пропонує Аиференціювати обсяг Аієздатності неповнолітніх фізичних осіб внаслідок неподібності ступеня їх соціальної зрілості на Аві групи: з 14 до 16 років та 16 ло 18 років. Така Аиференціація має проводитися в контексті участі неповнолітніх осіб у конкретних особистих немайнових і конкретних майнових правовідносинах з урахуванням знань педагогічної психології [5, с. 415].

Характерним також $є$ те, що особи віА 16 років можуть Аостроково набути повної АієзАатності, тобто бути емансипованими, внаслідок чого вони мають право вчиняти будь-які правочини на рівні з повнолітніми особами, які відповідно до віку набули повної дієздатності. Ця норма закріплена в ЦК України, зокрема це випадки, коли неповнолітня особа (яка Аосягла 16-річного віку) працює за трудовим Аоговором або реєструється як суб'єкт піАприємницької Аіяльності; у разі народження Аитини (незалежно віА віку) або вступу Ао шлюбу (за рішенням суАу після Аосягнення 16-річного віку) особа набуває повної цивільної Аієздатності.

В цьому випадку неповнолітні мають такі самі права і обов'язки, як і особи, які досягли 18 років (самостійно укладають будь-які правочини, віАповідають за Аоговірними зобов'язаннями, за зобов'язаннями, які виникають внаслідок запоАіяння шкоАи тощо). ПіАтверАженням повної цивільної дієздатності фізичної особи, яка Аосягла 16 років, є рішення органу опіки та піклування про надання такій особі повної цивільної Аієздатності, а в разі віАсутності такого рішення - віАповіАне рішення суду.

Висновки 3 АосліАження та перспективи подальших розвідок у цьому напрямі. Неповномітня особа має Аосить значне коло можливостей щодо вчинення правочинів самостійно (порівняно з малолітньою особою), однак існує і значна кількість обмежень, які передбачають необхіАність отримання Аозволу законних представників або ж визнання такого правочину недійсним.

Аналіз розвитку цивільних правовіАносин, інформаційного суспільства, впроваАження інформаційних технологій у повсякденне життя Аає підстави говорити про те, що "де-факто" має місце розширення кола та можливостей вчинення правочинів неповнолітніми особами, що пояснюється активним використанням технологій, розширенням можливостей заробітку (в тому числі он-лайн) такої категорії осіб, а також спричинено спонуканням держави до використання цифрових технологій. ОАним із таких сервісів 
$\epsilon$ портал Аія, на якому осіб, яким виповнилося 14 років, називають "майже Аорослими". На цьому порталі міститься вся інформація щодо можливості отримання паспорту громадянина України та паспорту Аля виїзду за кордон, перемічені загальні та сімейні права, надана інформація щодо цивільної відповідальності та відповіАальності за злочини тощо.

Все зазначене вище свідчить на користь необхіАності подальших більш Аетальних АосліАжень питань визначення кола правочинів, які можуть вчиняти неповнолітні особи, та обсягу їх дієздатності 3 урахуванням розвитку інформаційних технологій і цифровізації суспільства. Слушним $€$ й виділення Авох груп неповнолітніх осіб (віА 14 ло 16 років та віА 16 ло 18 років), що Аасть можливість в межах кожної групи визначити можмивість вчиняти ті чи інші правочини залежно віА участі неповнолітніх осіб в конкретних особистих немайнових і конкретних майнових правовіАносинах з урахуванням основних механізмів спрямованої соціалізації особи.

\section{NITEPATУPA:}

1. Ц Цивільний кодекс України: постатейний коментар у 2-х ч. / За ред. А.С. Довгерт, Н.С. Кузнєцова. К. : Юстініан, 2005.680 с.

2. Про затвердження Інструкції про порядок відкриття і закриття рахунків клієнтів банків та кореспондентських рахунків банків-резидентів і нерезидентів : Постанова Правління Національного банку України від 112.11.2003 № 492. URL: https://zakon.rada.gov.ua/laws/show/z1172-03

3. Смородина А. Часткова та неповна цивільна дієздатність фізичної особи: розпорядження майновими правами інтелектуальної власності. Підприємство, господарство і право. 2019. № 4. С. 70-75.

4. Ромовська 3.В. Українське цивільне право. Загальна частина : підручник для вузів. 3-тє вид., доп. К. : Дакор, 2013. 670 с.

5. Чалий Ю.І. Цивільна правосуб'єктність неповнолітніх: окремі проблемні аспекти. Форум права. 2014. № 3. С. $412-416$.

6. Дербакова Ю.А. Цивільна правосуб'єктність неповнолітніх : дис. канд. юрид. наук: 12.00.03. Одеса, 2014. 215 с.

\section{Тищук Наталія Олексіївна \\ ВЧИНЕННЯ ПРАВОЧИНІВ НЕПОВНОЛІТНІМИ ОСОБАМИ В УМОВАХ РОЗВИТКУ ІНФОРМАЦІЙНИХ TEXНОЛОГІЙ}

Стаття присвячена аналізу правочинів, які вчиняються неповнолітніми особами в умовах стрімкого розвитку інформаційних технологій і масового переходу на покупки в режимі онлайн, безготівкові форми розрахунків, впровадження різного роду сервісів, які обслуговують цю сферу, що свідчить про необхідність розширення фактичних можливостей неповнолітніх вчиняти правочини та вчинення їх в межах правових норм.

Встановлено, що неповнолітні особи самостійно можуть вчиняти такі види правочинів: правочини, які знаходяться в межах їх цивільної дієздатності та відповідно до законодавства можуть вчинятися самостійно (зокрема, це Арібні побутові правочини); укладати договір банківського вкладу (рахунку) та розпоряджатися вкладом, внесеним на своє ім'я (грошовими коштами на рахунку); правочини, які знаходяться поза межами цивільної дієздатності і які згодом були схвалені батьками (усиновлювачами) або одним з тих, з ким проживає неповнолітня особа, або піклувальниками; розпоряджатися своїм заробітком, стипендією або іншими Аоходами; зАійснювати особисті немайнові права на результати інтелектуальної, творчої діяльності, які охороняються законом; бути учасником (засновником) юридичних осіб, якщо це не заборонено законом або установчими документами юриличної особи; а також за згодою батьків (усиновлювачів) або піклувальників неповнолітні особи можуть розпоряджатися грошовими коштами, внесеними повністю або частково іншими особами у фінансову установу на їх ім'я; вчиняти правочини щодо транспортних засобів або нерухомого майна.

Зроблено висновок про існування більш широкого кола та можливостей вчинення правочинів неповнолітніми особами, ніж закріплено законодавчо, що пояснюється активним використанням технологій, розширенням можливостей заробітку (в тому числі онлайн) такої категорії осіб, а також спричинено спонуканням держави Ао переходу до використання цифрових технологій.

Встановлено необхідність Аиференціювати обсяг Аієздатності неповнолітніх осіб внаслідок неподібності ступеня їх соціальної зрілості на дві групи: з 14 до 16 років та з 16 до 18 років, що має враховувати участь неповнолітніх осіб в конкретних особистих немайнових і конкретних майнових правовіАносинах з урахуванням основних механізмів спрямованої соціалізації особи.

Киючові слова: правочин, Аієздатність, неповнолітня особа, інформаційні технології, емансипація неповнолітньої особи.

\section{Tyshchuk Nataliia \\ COMMITTING OF TRANSACTIONS BY MINORS IN THE CONDITIONS OF DEVELOPMENT OF INFORMATION TECHNOLOGIES}

The article is devoted to the analysis of transactions made by minors in the conditions of rapid development of information technologies and the mass transition to online purchases, non-cash forms of payment, implementation 
of various services that serve the area, which indicates the need to expand the actual capacity of minors and minors within the legal framework.

It is established that minors can independently perform the following types of transactions: transactions that are within the limits of their civil capacity and according to the law can be done independently (in particular, small household transactions); to enter into a contract of bank deposit (account) and to manage a deposit made in its own name (cash on account); transactions that are beyond the capacity of the child and subsequently approved by the parents (or adoptive parents), or one of them with whom the minor resides, or guardians; manage your earnings, scholarships or other income; exercise personal non-proprietary rights to the results of intellectual and creative activities protected by law; be a party (founder) of legal entities, unless prohibited by law or constituent documents of a legal entity; as well as with the consent of parents (adoptive parents) or guardians, minors may: dispose of funds deposited in full or in part by other persons in the financial institution in their name; make transactions in relation to vehicles or real estate.

The conclusion is made of the existence of a wider range and possibilities of committing transactions by minors, than it is enshrined in legislation, which is explained by active use of technologies, expansion of earning opportunities (including on-line) of such category of persons, as well as induced by the state to switch to the use of digital technologies.

The need to differentiate the capacity of minors due to the inappropriateness of their degree of social maturity into two groups: from fourteen to sixteen years, and from sixteen to eighteen years, which should take into account the participation of minors in specific personal non-pecuniary property persons.

Key words: legal transaction, legal capacity, minor, information technology, emancipation of a minor. 